\title{
Phytochemical profile and antimicrobial properties of Lotus spp. (Fabaceae)
}

\author{
FELIPE A. GIRARDI ${ }^{1}$, FABIANA TONIAL ${ }^{2}$, SILVIA O. CHINI $^{3}$, ANDRÉA M. SOBOTTKA ${ }^{1}$, \\ SIMONE M. SCHEFFER-BASSO ${ }^{3}$ and CHARISE D. BERTOL ${ }^{1 *}$ \\ ${ }^{1}$ Instituto de Ciências Biológicas, Universidade de Passo Fundo, BR 285, \\ Bairro São José, 99052-900 Passo Fundo, RS, Brasil \\ ${ }^{2}$ Departamento de Patologia Básica, Setor de Ciências Biológicas, Universidade Federal do Paraná, \\ Centro Politécnico, Jardim das Américas, 81540-970 Curitiba, PR, Brasil \\ ${ }^{3}$ Programa de Pós-Graduação em Agronomia, Faculdade de Agronomia e Medicina Veterinária, \\ Universidade de Passo Fundo, BR 285, Bairro São José, 99052-900 Passo Fundo, RS, Brasil
}

Manuscript received on May 27, 2013; accepted for publication on October 14, 2013

\begin{abstract}
The phytochemical profile and antimicrobial activity of cultivar (cv.) extracts of Lotus uliginosus (cvs. Trojan and Serrano), L. tenuis (cv. Larrañaga) and L. corniculatus (cv. São Gabriel) were investigated. The phytochemical analysis revealed tannins, coumarins and flavonoids in all extracts, with variations among cultivars, showing genotypic variability. By High Performance Liquid Chromatographic method, the cvs. Larrañaga and São Gabriel showed the highest percentage of catechin and epicatechin, respectively, and presented rutin, which was not detected in the other ones. These genotypes showed antifungal activity but not antibacterial one. The cv. Larrañaga inhibited the mycelia growth of Alternaria sp. and Fusarium graminearum while the cv. São Gabriel was active only against Alternaria sp. The cultivars showed the greatest amounts of secondary metabolites and demonstrated significant activity against filamentous fungi. The results provide a direction for further research about pharmacological use of Lotus spp.
\end{abstract}

Key words: Alternaria, flavonoids, Fusarium, tannins.

\section{INTRODUCTION}

The genus Lotus L. (Fabaceae), from the Mediterranean region, New Zealand and North America, contains approximately one hundred legume forage species. The main forage species of genus Lotus cultivated in South America are birdsfoot trefoil (Lotus corniculatus L.), narrow-leaf birdsfoot trefoil (L. tenuis Waldst \& Kit), great trefoil or major trefoil (Lotus pedunculatus Cav; syn.: L. uliginosus Schkuhr) and annual birdsfoot trefoil

Correspondence to: Charise D. Bertol

Email: charise@upf.br

*Curso de Farmácia
(L. subbiflorus Lag). One of its important traits is the highest tolerance to soil acidity in relation to other legumes, as alfalfa (Medicago sativa L.) and clovers (Trifolium spp.) (Izaguirre and Beyhaut 1998). Furthermore, the meteorism, a nutritional disorder, does not occur in ruminants that consume Lotus spp., due to the presence of condensed tannins (CTs) (Ramírez-Restrepo et al. 2004, Acuña et al. 2008), which precipitate the proteins, avoiding the formation of foam in the rumen.

Studies have demonstrated that CTs can also be an alternative to chemical anthelmintic to control gastro-intestinal parasitic nematodes. Legumes with a 
high content of CTs, like great trefoil, reduce worm burdens in grazing lambs by up to $50 \%$ (Niezen et al. 1995). Condensed tannin monomer units possessing cis stereochemistry are named epicatechin, epigallocatechin or epiafzelechin whereas those of trans stereochemistry are called catechin, gallocatechin or afzelechin (Naumann et al. 2013). Foo et al. (1996) found epicatechin, epigallocatechin and small amounts of units of epiafzelechin and catechin in birdsfoot trefoil. Besides tannins, Lotus spp. present flavonoids of flavonol type, like quercetin and kaempferol (Reynaud and Lussignol 2005), rutin and vitexin (Moro et al. 2010).

Tannins, terpenoids, alkaloids and flavonoids have shown antimicrobial properties in in vitro tests (Cowan 1999). Recent studies with birdsfoot trefoil cv. São Gabriel, showed important anti-inflammatory activity in a mouse model of pleurisy induced by carrageenan, its constituent's kaempferitrin, oleanolic acid and $\beta$-sitosterol may be the responsible for this (Koelzer et al. 2009). The crude extracted of this cultivar did not show any anti-bacterial activity, but the hexane fraction did, suggesting the pharmacological potential for a new anti-bacterial drug development (Dalmarco et al. 2010).

Due to antibiotic resistance and poor prospects for the development of new ones, the search for active substances has become a constant. Considering its agronomical importance and previous works about the phytochemical features in Lotus spp., this germplasm deserves further studies. This work aimed to evaluate the phytochemical profile and antimicrobial activity of hydromethanolic extracts of South American cultivars (cvs.) of great trefoil (cvs. Trojan and Serrano), narrow-leaf birdsfoot trefoil (cv. Larrañaga) and birdsfoot trefoil (cv. São Gabriel).

\section{MATERIALS AND METHODS}

\section{PLANT MATERIAL}

The biological material consisted of extracts of L. uliginosus (cvs. Trojan and Serrano), L. tenuis (cv. Larrañaga) and L. corniculatus (cv. São Gabriel). The plants were collected from the Experimental Station of Epagri (Empresa de Pesquisa Agropecuária e Extensão Rural de Santa Catarina), between May 2010 and November 2011, in Chapecó (SC), Brazil, at 679 m altitude, $27^{\circ} 07^{\prime} \mathrm{S}$ and $52^{\circ} 37^{\prime} \mathrm{W}$. The climate is subtropical Cfa type (Kuinchtner and Burial 2001). The soil type is Oxisol with pH 5.9. The aerial part of the plants (stem plus leaves) in vegetative stage was simultaneously collected.

\section{PREPARATION OF EXTRACTS}

The material was washed and air-dried at $35^{\circ} \mathrm{C}$ (Marconi/ MA 035/5) for 48 hours. The extracts were prepared by maceration with methanol: water (1:1) for ten days, followed by concentration in rotary evaporator (Buchi R-20) under reduced pressure at $70^{\circ} \mathrm{C}$. The Loss on Drying Test was performed to determine moisture and obtain the percentage of solids present in the extracts (Queiroz et al. 2002). For the phytochemical analysis the extracts were resuspended in methanol to a concentration of $50 \mathrm{mg} / \mathrm{mL}$ and filtered through a membrane of $0.45 \mu \mathrm{m}$. For antimicrobial activity the extracts were resuspended in water containing $1 \%$ dimethylsulfoxide (DMSO) to obtain final concentrations of $100 \mathrm{mg} / \mathrm{mL}$ and $1 \mathrm{~g} / \mathrm{mL}$, and then were filtered through a sterilizing membrane of $0.22 \mu \mathrm{m}$.

\section{PHYTOCHEMICAL ANALYSIS}

\section{General reactions}

Qualitative phytochemical tests for alkaloids, flavonoids and tannins were carried out using colorimetric and precipitation reactions (Simões et al. 2004, Matos 2009). Alkaloids were searched using the Mayer, Dragendorff, Bouchardt and Bertrand reagents. The screening for flavonoids occurred by reaction with 5\% aluminum chloride and observation of fluorescence in UV light $(365 \mathrm{~nm})$. 
To search for tannins the reactions were performed with a solution of $1 \%$ ferric chloride, $10 \%$ lead acetate and $1 \%$ gelatin in acidic media.

Thin-layer chromatography (TLC)

Phytochemical analysis in order to detect alkaloids, flavonoids, coumarins and tannins were achieved by TLC on silica gel F254 (Merck) plates. After elution with mobile phases (toluene: ethyl acetate: diethylamine, 7:2:1 and ethyl acetate: formic acid: water, 8.8:0.6:0.6), the plates were observed under ultraviolet light (wavelength $254 \mathrm{~nm}$ and $365 \mathrm{~nm}$ ) and revealed with: Dragendorff (alkaloids), NP/ PEG (1\% diphenylboriloxyethylamine in methanol $\mathrm{p} / \mathrm{v}$, followed by $5 \%$ polyethylene glycol 4000 in ethanol $\mathrm{p} / \mathrm{v}$ ) (flavonoids and coumarins), 10\% potassium hydroxide (coumarins) and 1\% ferric chloride (tannins) (Wagner et al. 1983, Rodrigues et al. 2009).

High-performance liquid chromatography (HPLC) analysis

To identify and quantify tannins and flavonoids, the HPLC methodology using reference standards (RS) of catechin (Sigma Aldrich BCBC2740), epicatechin (Sigma Aldrich BCBC8078V) and rutin (Sigma Aldrich BCBD8327V) was validated (S.O. Chini, unpublished data) following the official parameters (Brasil 2003, ICH 2005) (validation data were not shown). The extracts $(50 \mathrm{mg} / \mathrm{mL})$ and $\mathrm{RS}$ were diluted in methanol and a volume of $20 \mu \mathrm{L}$ was injected into the system in triplicate. Analyses were performed using RP $\mathrm{C}_{18}$ Brownlee (250 mm x $4.6 \mathrm{~mm}, 5 \mu \mathrm{m}$ ) column, without pre-column, on chromatograph LC Flexar Perkin Elmer (Burnsville, MN, USA) equipped with a binary pump, PDA detector (set at $282 \mathrm{~nm}$ ), autosampler, and the peak areas were integrated automatically by Chromera Workstation Software. The mobile phase, in isocratic system, consisted of acetonitrile and water acidified with phosphoric acid $(\mathrm{pH}=3)(18: 82)$ eluted at $1 \mathrm{~mL} / \mathrm{min}$.

\section{Antibacterial test}

For standardization of bacteria Staphylococcus aureus (ATCC 27213), Escherichia coli (ATCC 35219), Staphylococcus epidermidis (ATCC 12228), Pseudomonas aeruginosa (ATCC 27853) and Salmonella typhi (ATCC 19196), surfaces of Mueller Hinton agar containing the grown colonies were washed with sterile saline and diluted to $25 \%$ transmittance at a wavelength of $580 \mathrm{~nm}$ in spectrophotometer obtaining inoculum with approximately $10^{6} \mathrm{CFU} / \mathrm{mL}$. The antibacterial test was performed using the agar well diffusion method and microdilution broth (Michelin et al. 2005, Dias et al. 2006, Ostrosky et al. 2008). All samples were tested in triplicates.

By the agar well diffusion method, $100 \mu \mathrm{L}$ of the inoculum was dispersed with a sterile swab over the surface of Petri dishes containing $20 \mathrm{~mL}$ of MuellerHinton medium. The wells of $6 \mathrm{~mm}$ were made in agar, and $60 \mu \mathrm{L}$ of the extracts, at a concentration of $100 \mathrm{mg} /$ $\mathrm{mL}$, was added. Chloramphenicol (30 $\mu \mathrm{g} /$ disk) was used as a positive control and 1\% DMSO served as a negative control. After incubation of the plates for $24 \mathrm{~h}$ at $37^{\circ} \mathrm{C}$, zones of inhibition were measured.

Minimum inhibitory concentrations (MIC) were determined by microdilution broth. The extracts were diluted in a nutrient broth at the concentrations of 1:1 to $1: 32$. Microplates of ninety six wells were used, where $90 \mu \mathrm{L}$ of nutrient broth, $10 \mu \mathrm{L}$ of standardized inoculum and $100 \mu \mathrm{L}$ of dilutions of the extracts were added. After incubation of the plates for 24 hours at $37^{\circ} \mathrm{C}$, the microplates were observed for turbidity occurrence. Parallel controls were made: 1) positive (inoculum, nutrient broth and chloramphenicol $37.5 \mu \mathrm{g} / \mathrm{mL}$ ), 2) negative (inoculum and nutrient broth), 3) negative (inoculum, extracts diluent and nutrient broth), and 4) sterility control of the medium.

\section{Antifungal test}

The agar well diffusion method was also used to the Candida albicans (ATCC 10231). The inoculum was prepared by taking, as a standard, the scale 0.5 McFarland $\left(10^{6} \mathrm{CFU} / \mathrm{mL}\right)$ (CLSI 
2003). DMSO 1\% was used as a negative control and nystatin $10.0000 \mathrm{IU} / \mathrm{mL}$ served as a positive control. The extracts were added to the wells at concentration of $100 \mathrm{mg} / \mathrm{mL}$ and $1 \mathrm{~g} / \mathrm{mL}$. The plates were incubated for $48 \mathrm{~h}$ at $25^{\circ} \mathrm{C}$, and, then, the inhibition zones were analyzed. The assay was performed in triplicate.

Antifungal activity was tested against the filamentous fungi Alternaria sp. and Fusarium graminearum. Extracts aliquots of $100 \mu \mathrm{L}(1 \mathrm{~g} /$ $\mathrm{mL}$ ) were added and uniformly distributed, with Drigalsky handle, on petry plates surfaces with potato dextrose agar. A mycelial disc $(6 \mathrm{~mm}$ diameter) taken from the edge of a colony in activity growth was positioned at the center of each plate. The positive controls for Alternaria and Fusarium were glyphosate $(10 \mathrm{mg} / \mathrm{mL})$ and carbendazim (20 ppm), respectively. The negative control was the DMSO (1\%).

The plates were incubated at $28^{\circ} \mathrm{C}$ for 6 days for Alternaria sp. and 3 days for Fusarium sp. The colony diameter, in two perpendicular directions, was measured every 2 days for Alternaria sp. and daily for Fusarium sp. The test was conducted in five replicates. The percentage inhibition of diameter growth (PIDG) of the extracts on the fungal growth, which means the antifungal activity of the extracts, was determined according to the formula below.

$$
P I D G=\{[(E d / C d) \times 100]-100\}
$$

In which Ed means the average diameter ( $\mathrm{mm}$ ) of the mycelia with the extract, and $\mathrm{Cd}$ means the average diameter $(\mathrm{mm})$ of the mycelia with the negative control (Yang et al. 2012, with brief modifications).

\section{Statistical analysis}

Statistical analysis was performed using one-way analysis of variance (ANOVA) and the means were compared by Tukey test at 5\% significance level.

\section{RESULTS AND DISCUSSION}

PHYTOCHEMICAL ANALYSIS

The phytochemical analysis detected variations among cultivars, showing genotypic differences, despite the plants being grown and collected in the same location simultaneously. The positive reactions for alkaloids were obtained for all extracts only after addiction of Dragendorff reagent. For cv. São Gabriel, this also occurred after addiction of Bouchardt reagent. The occurrence of precipitation for only two of the reagents used (Dragendorff, Bouchardt) cannot be considered indicative of alkaloids. These reagents are not specific and the presence of proteins, purins, betains, coumarins and others may also cause positive reactions (Henriques et al. 2004). Characteristic pattern of spots of alkaloids were not visualized in TLC, not confirming the presence of these metabolites in the studied plants. The results are in agreement with Moro et al. (2010) who did not find alkaloids in cvs. São Gabriel, Maku (L. uliginosus) and El Rincón ( $L$. subbiflorus) in both colorimetric reactions and TLC.

The presence of coumarins and flavonoids was detected in all extracts, through TLC. Greater contents of coumarins (blue fluorescence spots) and flavonoids (orange spots) were observed in extracts of cvs. Larrañaga and São Gabriel under UV light $(365 \mathrm{~nm})$ intensified after the use of revelators (NP/PEG and potassium hydroxide). Blue and green spots were observed through fluorescence light in the cvs. Trojan and Serrano, indicating the presence of phenyl carbonic acids, a type of chlorogenic and isochlorogenic acids (Wagner et al. 1983). These results confirm previous studies regarding the presence of flavonoids in Lotus spp. (Basualdo et al. 2003, Reynaud and Lussignol 2005, Moro et al. 2010).

The presence of condensed tannins was observed in all cultivars, with the greatest content in the cvs. Larrañaga and São Gabriel (especially after the use of ferric chloride in TLC). HPLC 
analysis proved to be conclusive for the presence of tannins and flavonoids in all cultivars. Condensed tannin monomers (catechin and epicatechin) were observed in all extracts, but in different amounts. The percentage (w/w on dry extract) of catechin was 0.29 (cv. Trojan), 0.23 (Serrano), 0.66 (cv. Larrañaga) and 0.58 (cv. São Gabriel). The concentrations of epicatechin were $0.59 \%$ (cvs. Trojan and Serrano), 0.91\% (cv. Larrañaga) and $2.54 \%$ (São Gabriel). The flavonoid rutin was only found in the cvs. Larrañaga $(0.88 \%)$ and São Gabriel $(0.29 \%)$. The cvs. Trojan and Serrano, being of the same species (L. uliginosus), showed a very similar chromatographic profile, suggesting that secondary metabolites are genetically related (Figure 1).

\section{ANTIMICROBIAL TEST}

Antibacterial activity of Lotus spp. extracts was not observed. The birdsfoot trefoil cv. São Gabriel hydroalcoholic extract and its fractions were already described as inactive against gram-negative bacteria and with a weak to moderate activity against gram-positive bacteria. The increase of antibacterial activity (especially gram-positive) was obtained after the isolation of the oleanolic acid and kaempferitrin compounds (Dalmarco et al. 2010, Koelzer et al. 2009). The extracts of Lotus spp. also showed no activity against the yeast Candida albicans. However, effects were observed on Alternaria sp. and Fusarium sp. subjected to treatment with $100 \mu \mathrm{L}$ of extracts (Figure 2).

The percentage inhibition of diameter growth (PIDG) of Alternaria sp. after 6 days of incubation treated with the extracts of cvs. Trojan, Serrano, Larrañaga and São Gabriel were $-6.07 \%$, $1.29 \%,-12.34 \%$ and $-16.94 \%$, respectively. The negative signals demonstrated the reduction in the fungus growth that was significant $(p<0.05)$ after treatment with the extracts. The extract of cv. São Gabriel presented the best result, followed by cvs. Larrañaga and Trojan. Fusarium sp. proved to be less sensitive to the extracts, and the PIDG after 3 days of incubation was 11.44 (cv. Trojan), 10.45 (Serrano), -9.29 (cv. Larrañaga) and 7.30 (São Gabriel). The inhibition of fungal growth was significant $(\mathrm{p}<0.05)$ with the extract of $\mathrm{cv}$. Larrañaga (Table I).

There are reports of antifungal activity of extracts of Lotus garcinii DC. for Aspergillus niger, Alternaria solani, Penicillium funiculosium, Microsporum canis and Pleuroetus oustreatus (Azhar et al. 2004). In this study, the extracts of cvs. Larrañaga and São Gabriel significantly $(p<0.05)$ inhibited the mycelia growth, at least in one of the fungi tested, indicating the importance of evaluating different species and cultivars. These cultivars showed the greatest contents of coumarins, flavonoids and tannins by TLC (by strong and numerous spots), and catechin, epicatechin and rutin by HPLC. These compounds are directly related to antifungal activity. The antimicrobial action of the flavonoids may be related to the ability to bind with extracellular and soluble proteins and also with cell wall structures. The most lipophilic flavonoids may act causing the disruption of microbial membranes (Mota et al. 2009, Sandhar et al. 2011). Other studies have demonstrated the antifungal activity of flavonoids in an important legume species, Desmodium caudatum (Thunb.) DC (Sasaki et al. 2012). Regarding tannins, the action mechanism can be explained by the inhibition of fungal enzymes and/or binding the enzyme substrates. The action of tannins on cell membranes of microorganisms can modify their metabolism. Furthermore, the bind of the tannins with metal ions reduces the availability of these ions, which are essential for microbial metabolism (Mota et al. 2009).

The antifungal activity of Lotus cultivar extracts against filamentous fungi must be explored, searching for the elucidation of these compounds and their mode of action, as well as the effects on other fungus. The results provide a direction for further research about pharmacological use of Lotus spp.. 

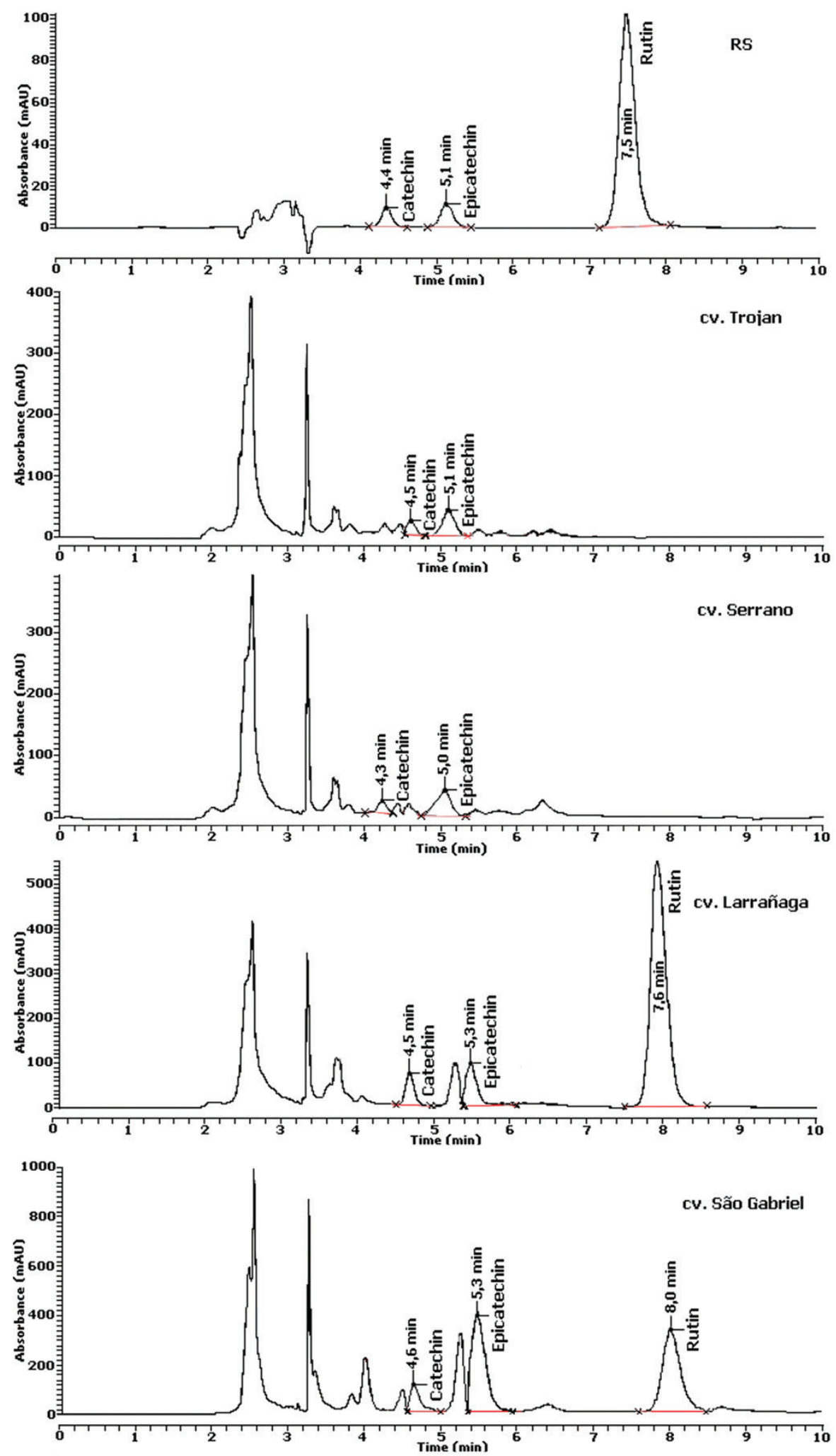

Figure 1 - Chromatograms obtained by HPLC for RS (catechin, epicatechin and rutin) and for Lotus spp. cultivars. 


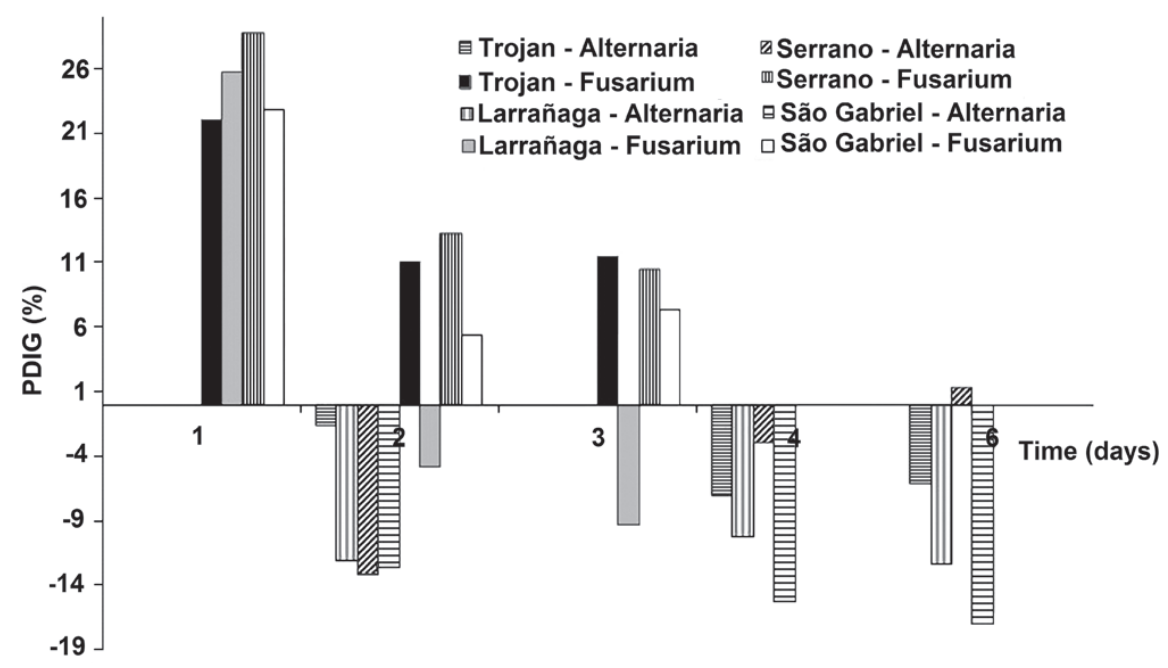

Figure 2 - Percentage inhibition of diameter growth (PIDG) of the fungus Alternaria sp. (measurements in 2, 4 and 6 days) and Fusarium sp. (measurements in 1, 2 and 3 days) following treatment with extracts of Lotus spp. cultivars.

TABLE I

Fungal mycelia growth in response to treatments with $100 \mu \mathrm{L}$ of extracts of Lotus spp. cultivars compared with the negative control treatment.

\begin{tabular}{ccc}
\hline Treatment $(100 \mu \mathrm{L})$ & \multicolumn{2}{c}{ Fungal mycelia growth $(\mathrm{cm})$} \\
\cline { 2 - 3 } & Alternaria sp. $^{*}$ & Fusarium sp. $^{*}$ \\
\hline Negative control & $5.43^{\mathrm{a}}$ & $6.03^{\mathrm{b}}$ \\
Trojan & $5.10^{\mathrm{ab}}$ & $6.72^{\mathrm{a}}$ \\
Serrano & $5.50^{\mathrm{a}}$ & $6.66^{\mathrm{a}}$ \\
Larrañaga & $4.76^{\mathrm{b} * *}$ & $5.47^{\mathrm{c} * *}$ \\
São Gabriel & $4.51^{\mathrm{b} * *}$ & $6.47^{\mathrm{a}}$ \\
\hline
\end{tabular}

*Data obtained on the $3^{\text {rd }}$ day of measurement: for Alternaria sp. after 6 days of incubation, and for Fusarium sp. after 3 days of incubation. Means followed by the same letter in the column do not differ significantly (Tukey test, $\mathrm{p}<0.05$ ).

** Significantly mycelia growth inhibition compared to the negative control.

\section{ACKNOWLEDGMENTS}

The authors acknowledge the financial support received from Fundação de Amparo à Pesquisa do Estado do Rio Grande do Sul (FAPERGS, process 1014579/2010) and Conselho Nacional de Desenvolvimento Científico e Tecnológico (CNPq, process 479283/2011-7).

\section{RESUMO}

$\mathrm{O}$ perfil fitoquímico e a atividade antimicrobiana de extratos de cultivares (cvs.) de Lotus uliginosus (cvs. Trojan e Serrano), L. tenuis (cv. Larrañaga) e $L$. corniculatus (cv. São Gabriel) foram investigados. A análise fitoquímica revelou taninos, cumarinas e flavonoides em todos os extratos, com variação entre os cvs., demonstrando variabilidades genotípicas. Pelo método de Cromatografia Líquida de Alta Eficiência, os cvs. Larrañaga e São Gabriel apresentaram os maiores percentuais de catequina e epicatequina, respectivamente, e apresentaram rutina, que não foi detectada nos demais. Tais genótipos apresentaram atividade antifúngica, mas não mostraram atividade antibacteriana. $\mathrm{O}$ cv. Larrañaga inibiu o crescimento micelial de Alternaria sp. e Fusarium graminearum enquanto o cv. São Gabriel foi ativo somente contra Alternaria sp.. Os cultivares que apresentaram as maiores quantidades de metabólitos secundários, demonstraram atividade significativa contra fungos filamentosos. Os resultados fornecem indicativos para futuras pesquisas sobre a utilização farmacológica de Lotus spp.

Palavras-chave: Alternaria, flavonoides, Fusarium, taninos.

\section{REFERENCES}

Acuña H, Concha A And Figueroa M. 2008. Condensed tannin concentrations of three Lotus species grown in different environments. Chilean J Agric Res 68: 31-41.

AZHAR I, MAZHAR F, AHMAD SW, USMANGHANI K AND GILL MA. 2004. Antifungal screening of Lotus garcinii D. C. Pak J Pharmacol 21: 7-10. 
Basualdo N, Quintana E, Mendoza R and Del Pero MARTíneZ MA. 2003. Quimiosistematica en ecotipos de Lotus glaber (Fabaceae). Bol Soc Argent Bot 38: 204.

BRASIL. 2003. AGÊNCIA NACIONAL DE VIGILÂNCIA SANITÁRIA (ANVISA). Resolução Executiva Nº 899, Guia para validação de métodos analíticos e bioanalíticos. Available at, http://www.anvisa.gov.br. Access, 15 December 2012.

CLSI. 2003. Padronização dos testes de sensibilidade a antimicrobianos por disco-difusão; Norma aprovada, $8^{\mathrm{a}}$ edição, M2-A8. Clinical and Laboratory Standards Institute. Pennsylvania: CLSI.

COWAN MM. 1999. Plant products as antimicrobial agents. Clin Microbiol Rev 12: 564-582.

Dalmarco JB, Dalmarco EM, Koelzer J, Pizzolatti MG AND FRODE TS. 2010. Isolation and identification of bioactive compounds responsible for the anti-bacterial efficacy of Lotus corniculatus var. São Gabriel. Int J Green Pharm 4: 108-114.

Dias JFG, Virtuoso S, Davet A, Cunico MM, Miguel MD, Miguel OG, AuER CG, Grigoletti-JÚNior A, OliveirA AB AND FERRONATO ML. 2006. Atividade antibacteriana e antifúngica de extratos etanólicos de Aster lanceolatus Willd., Asteraceae. Rev Bras Farmacog 16: 83-87.

Foo LY, NEWMAN R, WAGHORN G, MCNABB WC AND UlyatT MJ. 1996. Proanthocyanidins from Lotus corniculatus. Phytochemistry 41: 617-624.

Henriques AT, Limberger RP, Kerber VA AND Moreno PRH. 2004. Alcaloides: generalidades e aspectos básicos. In: SIMÕES CMO, SCHENKEL EP, GOSMANN G, MELLO JCP, MENTZ LA AND PETROVICK PR (Orgs), Farmacognosia: da planta ao medicamento. Porto Alegre/ Florianópolis: Ed. UFRGS/ Ed. UFSC, p. 765-791.

ICH. 2005. International Conference on Harmonization of Technical Requirements for Registration of Pharmaceuticals for Human Use, Q2(R1): Validation of Analytical Procedures: Text and Methodology.

IZAGUIRRE P AND BEYHAUT R. 1998. Las leguminosas en Uruguay y regiones vecinas. Montevideo: Editorial Agropecuaria Hemisferio Sur, 549 p.

Koelzer J, Pereira DA, Dalmarco JB, Pizzolatti MG and FRÖDE TS. 2009. Evaluation of the anti-inflammatory efficacy of Lotus corniculatus. Food Chem 117: 444-450.

KuinchtNer A AND Burial GA. 2001. Clima do estado do Rio Grande do Sul segundo a classificação de Köppen e Thornthwaite. Discipl Sc 2: 171-182.

MATOS FJA. 2009. Introdução à fitoquímica experimental, Fortaleza: Edições UFC, 141 p.

Michelin DC, MoRESchi PE, Lima AC, NASCimento GGF, Paganelli MO AND Chaud MV. 2005. Avaliação da atividade antimicrobiana de extratos vegetais. Rev Bras Farmacogn 15: 316-320.

Moro GV, SchefFer-BAsso SM, AbDalla AL, REgINATTO FH, PeÇAnHA MR AND Costa GM. 2010. Aspectos químicos do gênero Lotus L. com ênfase em metabólitos secundários. ARS Vet 26: 113-119.
Mota BCF, SOUZA LM, Mercadantes-SimÕES MO, FERNANDES MFG AND SANTOS HCM. 2009. Atividade antifúngica e antibacteriana de metabólitos secundários de plantas. In: III Fórum de Ensino, Pesquisa, Extensão e Gestão. Montes Claros: Editora da Unimontes.

NAUMANN HD, Muir JP, LAMBERT BD, TEDESCHI LO AND KotHMANN MM. 2013. Condensed tannins in the ruminant environment: a perspective on biological activity. J Agric Sci 1: 8-20.

NiEZEN JH, WAGHORN TS, CHARLESTON WAG AND WAGHORN GC. 1995. Growth and gastrointestinal nematode parasitism in lambs grazing either lucerne (Medicago sativa) or sulla (Hedysarum coronarium) which contains condensed tannins. J Agric Sci Camb 125: 281-289.

Ostrosky EA, Mizumoto MK, Lima MEL, KANEKo TM, NishIKAWA SO AND FREITAS BR. 2008. Métodos para avaliação da atividade antimicrobiana e determinação da concentração mínima inibitória (CMI) de plantas medicinais. Rev Bras Farmacogn 18: 301-307.

QueIroz CRAA, MORAIS SAL AND NASCIMENTO EA. 2002. Caracterização dos taninos da aroeira-preta (Myracrodruon urundeuva). Rev Arvore 26: 485-492.

RAMÍREZ-RESTREPO CA, BARRY TN, LÓPEZ-VILLALOBOS N, KEMP PD AND MCNABB WC. 2004. Use of Lotus corniculatus containing condensed tannins to increase lamb and wool production under commercial dryland farming conditions without the use of anthelmintic. Anim Feed Sci Technol 117: 85-105.

REYNAUD J AND LUSSIGNOL M. 2005. The flavonoids of Lotus corniculatus. Lotus Newsletter 35: 75-82.

RODRIGUES IMC, SOUZA FILHO APS AND FERREIRA FA. 2009 Estudo fitoquímico de Senna alata por duas metodologias. Planta Daninha 27: 507-513.

SANDhar HK, Kumar B, Prasher S, Tiwari P, SALHAN M AND SHARMA P. 2011. A review of phytochemistry and pharmacology of flavonoids. Int Pharm Sci 1: 25-41.

SASAKI H, KASHIWADA Y, SHIBATAV H AND TAKAISHI Y. 2012. Prenylated flavonoids from the roots of Desmodium caudatum and evaluation of their antifungal activity. Planta Med 78: 1851-1856.

Simões CMO, SchenKel EP, Gosmann G, Mello JCP, Mentz LA AND PETROVICK PR (Orgs). 2004. Farmacognosia: da planta ao medicamento. Porto Alegre/ Florianópolis: Ed. UFRGS/ Ed. UFSC, 1102 p.

WAGNER H, BLADT S AND Zgainski EM. 1983. Drogenanalyse. Dünnschichtchromatographische Analyse von Arzneidrogen. Berlin: Springer, $321 \mathrm{p}$.

Yang WJ, MiaO F, YaO Y, CaO FJ, Yang R, Ma YM, Quin BF AND ZHOU L. 2012. In vitro antifungal activity of sanguinarine and chelerythrine derivatives against phytopathogenic fungi. Molecules 17: 13026-13035. 